\title{
双ロール法における電磁気力を利用した 溶融金属パドル保持に関する安定性解析
}

\author{
古橋 誠治*・浅井 滋生*2
}

Stability Analysis for Confining Molten Metal Puddle by Electromagnetic Force in Twin Roll Process Seiji Furuhashi and Shigeo Asai

Synopsis : In order to make use of the electromagnetic force replacing a solid side dam to confine molten metal at the side edges in a twin roll caster, the stability analysis of an electromagnetic dam, where the vertical free surface of molten metal is held without any contact with a solid wall, has been studied. The electromagnetic dam which makes use of the electromagnetic force induced by the static magnetic field and the direct electric current is expected to avoid the troubles caused by the solid side dams in conventional operations. By using the normal mode method developed in the perturbation theory, the effects of operational variables such as imposed electric current, imposed magnetic field, and the imposing direction of magnetic field to that of a wave vector on the stability of the free surface of molten metal have been studied. This stability analysis derives that the better stability are found in the conditions with the less electric current, the stronger magnetic field, and the magnetic field parallel to the direction of a wave vector.

Key words : stability analysis; strip casting; twin roll ; steel making ; confinement of molten metal ; electromagnetic processing of materials; electromagnetic force; electromagnetic dam.

\section{1. 緒言}

溶融金属から薄板を直接鋳造するストリップキャスティ ングプロセスでは，熱間圧延工程の省略による製造コスト

の低減，急速凝固による組織の改善が期待できる1)。

上注ぎ双ロール法では二つのロール間に溶融金属を保持 する必要があり，耐火物製のサイド堰の押さえつけによる 方法が主流となっている。しかしロールとの直接接触のた めサイド堰の摩耗, ロールの熱歪等に起因してロールと堰 の間隙より溶湯の漏れが生ずる。また，この場合，三重点 (溶融金属一ロール一耐火物) を形成するため拘束性シェル が発達するなど連続操業の点で問題が残されている2)。の 問題に関して, 河地 $ら^{324)}$ は㨁流磁場 $と$ 直流電流の相互作用 により生ずる電磁気力を用いる電磁堰を提案した。そして 水平方向磁場一鉛直方向電流, 鉛直方向磁場一水平方向電 流の 2 タイプについて小型モデル機を用いた低融点金属の 鋳造実験を実施し，側端の非接触保持の可能性を示した。 また，従来のサイド堰に磁性体を埋め込んだ構造の堰を用 いて，堰とロールの間にわずかに間隙を設け摩耗を防止し た上で，その間隙の部分に電磁気力を生じせしめる併用型 電磁堰5)も提案している。しかし, 高周波磁場印加の場合と
は異なり安定化機能6)を持ち合わせていないため自由表面の 安定保持が大きな課題となる。

一方，直流磁場印加による溶融金属の自由表面波動抑制 効果は古くから知られており7), 様々な基礎的研究がなされ, 直流磁場の波動抑制効果は非等方的であることが確認され ている ${ }^{8) ~ 10)}$ 。直流磁場下の電磁流体を対象とした安定性に関

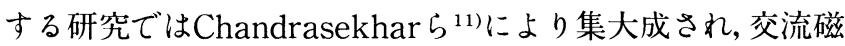

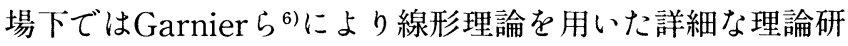
究がなされている。また実際のプロセスを対象とし，竹内 $ら^{12)}$ は水平式電磁鋳造における浮揚溶融部を対象とした安定 性解析を行った。そこでは臨界波長を算出することにより 安定溶融部長さを推算し, 安定化のための磁場印加方向の 影響が非等方的であることを理論解析により示している。

双ロール法における電磁気力による非接触電磁堰の適用 法として磁場印加方向の違いからみると, 水平方向磁場 鉛直方向磁場の二つのタイプがある。実操業での安定操業 や，効果的な適用を検討す心゙く，本報ではこれら二つのタ イプの安定性解析を行い, 保持された溶融金属自由表面に 及ぼす操作因子の影響および効果的な磁場印加方向を検討 した。 


\section{2. 理論解析}

\section{$2 \cdot 1$ 解析手法}

Normal mode法 ${ }^{11)}$ 用いて微小振幅波を対象とした線形 安定性解析を行う。定常状態にある流体に微小な乱れが生 じたときにその乱れの時間的変化を $e^{i s t}$ 関数 ( $s$ ：角振動数) とおき，基礎方程式や境界条件により求められる波数と角 振動数の関係式 (分散関係式) から，sの関数形が決定され る。 $s=s_{r}+i s_{i}$ ( $s_{r}$ : 実部, $s_{i}$ : 虚部) とおくと, 乱れは $\cos$ $\left(s_{r} t\right) \exp \left(-s_{i} t\right)$ と表される。したがって， $s_{i}<0$ のとき 乱れは時間の経過と共に増大して不安定, $s_{i}>0$ のときは逆 に, 減衰して安定, $s_{i}=0$ のとき乱れは成長も減衰もせず中 立安定となる。このように角振動数の虚数部 $s_{i}$ は波の振幅の 時間的な変化を与えるため, $s_{i}$ の関数形を求めることで任意 の波長を有する波の安定性解析が可能となる。以下に磁場 印加方向により分類して分散関係式を導出する。

\section{$2 \cdot 2$ 分散関係式の導出}

\section{$2 \cdot 2 \cdot 1$ 水平方向磁場}

ロール間に保持されるべき溶湯の側端部の模式困（波動 の生ずる自由表面を斜線部で示す。）と解析系をFig. 1 (a), (b)に示す。解析に当たっては次の仮定を設ける。（1）溶湯 は $x, z$ 方向には無限に, $y$ 方向には半無限に広がりを持ち, ロールとの接触および凝固シェルによる溶湯の拘束条件は 無視する。なお，第 3 章で後述するように，この仮定は口 一ルおよび凝固シェルの存在そのものを無視するのではな く，臨界波長との関係でそれらの存在は考虑されている。
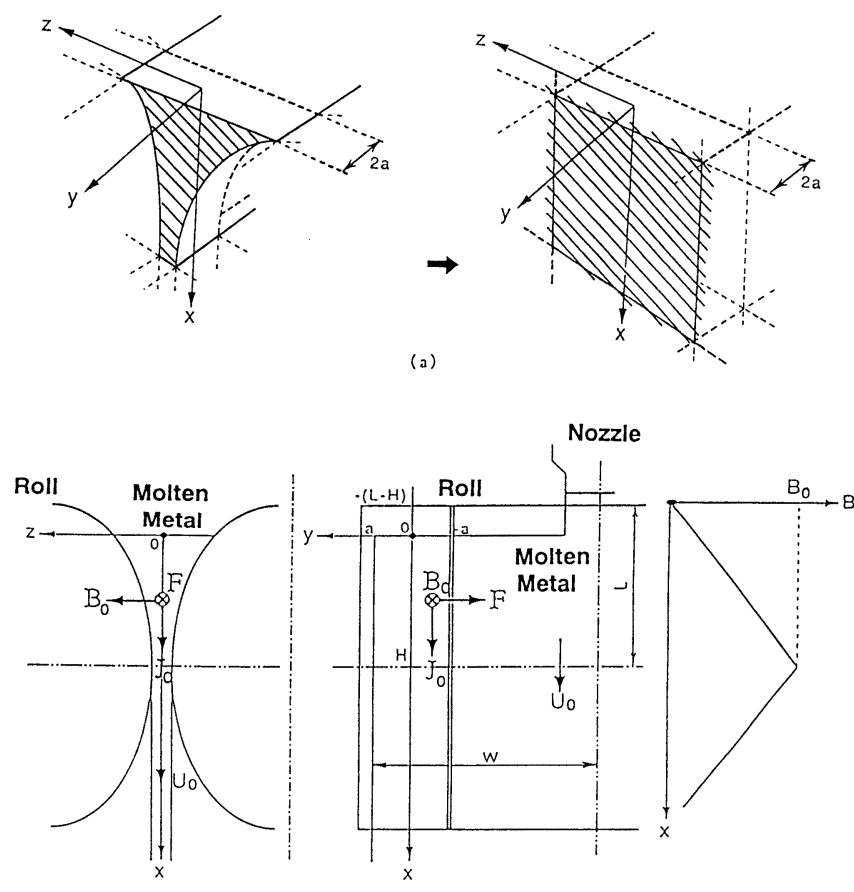

(b)

Fig. 1. Schematic view of a vertical edge surface of molten metal (a), the coordinate system in the horizontal magnetic field (b).
（2）平衡状態では，鉛直端面は電磁気力 溶湯静圧で $y=$ $a$ の面内に保持される。( 3 ) 流体の密度は均一である。(4) 自由空間の電気伝導度 $\sigma$ 零である。( 5 ) 溶湯は完全流体 とし，粘性項を無視する。

ロールは $y>-a$ 範囲のみ磁性体で作られているため, 外部印加磁束密度は $\boldsymbol{B}_{0}=\left(0,0, B_{0}\right)$ と表し, $y>-a$ に存 在する。ロールを利用した磁気回路を形成して磁場を発生 させるためロールキス部で最も強くなり磁束密度には勾配 が存在する。外部印加電流密度はロール側端のみに電流が 印加されるとし， $-a<y<a て ゙$ 均一で， $\boldsymbol{J}_{0}=\left(J_{0}, 0,0\right)$ と おき, 流体移動速度は $\boldsymbol{U}=\left(U_{0}, 0,0\right)$ と寸る。磁束密度は 外部印加電流により生じる誘導磁束も考虑すると次のよう になる ${ }^{13)}$ 。

$$
\begin{gathered}
\boldsymbol{B}_{m}=\left(0,0, B_{0}+\mu_{0} J_{0} y\right):-a<y<a, \\
\boldsymbol{B}_{m}=\left(0,0,-\mu_{0} J_{0} a\right): y<-a \cdots \cdots
\end{gathered}
$$

溶湯の進む方向は磁場の方向と直交し, 溶湯は磁場勾配 が増加する方向に進むため勾配を持った電場が誘導される。 本解析においては流体は無限の大きさを仮定しているが， 双ロール電磁堰においてはFig. 2 のように溶湯をロールの両 端で電磁気力により保持するため, 左右対称に電場勾配が 生じる。その結果，溶融金属流の幅方向 $(x-y$ 面)に2 の電流ループが生じる。したがって誘導電流は以下の関係 式を満なす（導出は付録参照）。

$\partial J_{y} / \partial x-\partial J_{x} / \partial y=-\sigma U_{0} B_{0} / L:-(L-H) \leqq x \leqq H$
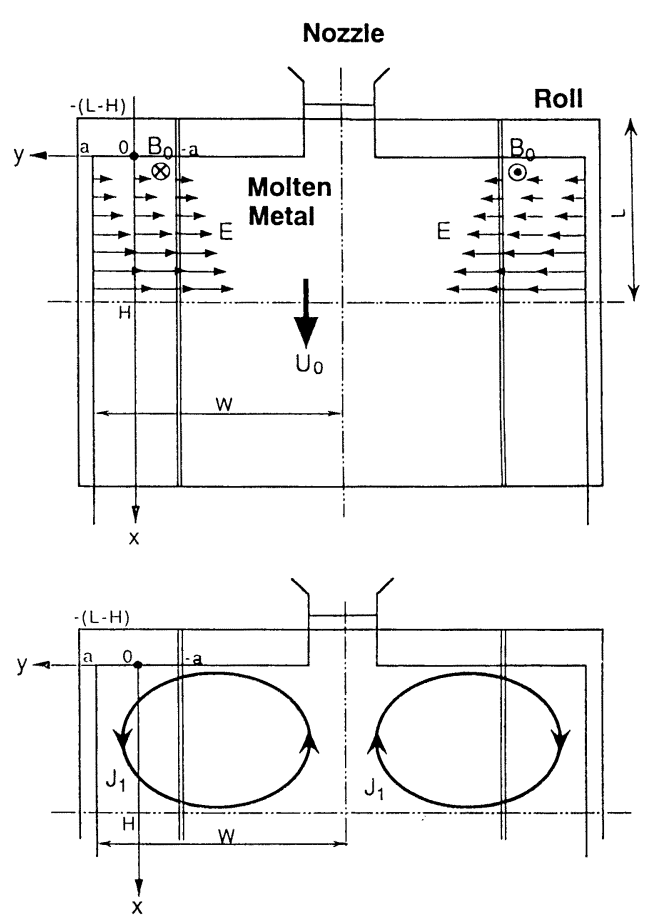

Fig. 2. Schematic view of the induced electric field and the induced eddy current loop. 
また,この電流ループにおいてーaから、においては $x$ 成分が 主であるため, 計算を簡略化する目的で $J_{y}$ を無視し, 式 $(3)$ とする。

$$
d J_{x} / d y=\sigma U_{0} B_{0} / L
$$

ループ幅中心で誘導電流の $x$ 成分が零となる条件式 $(4)$ に基 づいて式( 3 ) を解くと式( 5 ) が得られる。

$$
\begin{aligned}
& J_{x}=0: y=-\{(W / 2)-a\} \cdots \cdots \\
& J_{x}=\left(\sigma U_{0} B_{0} / L\right)\{y+(W / 2)-a\}
\end{aligned}
$$

誘導電流も含めて, 電流密度は次のように求められる。

$$
\begin{aligned}
& \boldsymbol{J}_{m}=\boldsymbol{J}_{0}+\boldsymbol{J}_{1}=\left(J_{0}+P_{1} y+Q_{1}, \quad 0,0\right), \\
& P_{1}=\left(\sigma U_{0} B_{0} / L\right), \quad Q_{1}=\left(\sigma U_{0} B_{0} / L\right)\{(W / 2)-a\}
\end{aligned}
$$

またy方向の電磁気力は次式で与えられる。

$$
\begin{aligned}
& F_{y}=\left(\boldsymbol{J}_{m} \times \boldsymbol{B}_{m}\right)_{y}=-\left(J_{0}+P_{1} y+Q_{1}\right)\left(B_{0}+\mu_{0} J_{0} y\right): \\
& -a<y<a \text {. }
\end{aligned}
$$

これを電流と磁場の印加領域である $y$ 方向に一 $a$ から $a$ まで積 分したものが常に溶湯静圧と釣り合っているとすれば式（８） が得られる。ただし表面張力の影響は小さいため無視し， 釣合の位置を溶湯保持が最も難しいロールキス部の位置 $H$ とする。

$$
\left|\int_{-a}^{a} F_{y} d y\right|=\rho g H
$$

したがって釣合条件として次式が得られ， $B_{0}$ に関する 2 次 方程式を解けば磁束密度 $B_{0}$ の值が求まる。

$$
J_{0} B_{0}=(\rho g H / 2 a)-\left(\mu_{0} J_{0} a^{2} P_{1} / 3\right)-Q_{1} B_{0}
$$

表面に生ずる攪乱 $\delta$ は $x, z$ 方向に周期的であると仮定し， さらに攪乱された表面の位置を $y=a+\delta y_{s}$ とすると, 表面攪 乱の形は次のようにおける。

$$
\begin{aligned}
& \delta y_{s}=\varepsilon_{0} \exp (i s t) \exp \left(i k_{x} x+i k_{z} z\right) \\
& \boldsymbol{k}=\left(k_{x}, 0, k_{z}\right), \quad k^{2}=k_{x}{ }^{2}+k_{z}{ }^{2} \ldots
\end{aligned}
$$

速度，圧力，密度の攪乱は，表面攪乱と同様に 2 次元周期 波の基本モードを有するものと考える。攪乱を受けた Navier - Stokes方程式から攪乱のない式を差し引くと, 変 動量を支配する攪乱の方程式 (12)が得られる。ただし，攪 乱の 2 次以上の微小項は無視して線形化している。

$$
\rho(\partial \boldsymbol{u} / \partial t)+\boldsymbol{U} \cdot \nabla \rho \boldsymbol{u}=-\nabla p+\delta \rho \boldsymbol{g}+\boldsymbol{f}
$$

次に界面での攪乱の式を求める。境界面での微小振幅波 動において, 界面での境界条件に表面張力項を加えて, 成 分ごとにそれぞれ表すと

$$
\begin{aligned}
& i\left(s+k_{x} U_{0}\right) \rho u_{x}=-i k_{x} p_{0}+f_{x}+\delta \rho g \quad \cdots \cdots \cdots \cdots \cdots \cdots \cdots \\
& i\left(s+k_{x} U_{0}\right) \rho u_{y}=-\partial p_{0} / \partial y+f_{y}-T_{s} k^{2} \delta_{d}\left(y-y_{s}\right) \delta y_{s} \cdots
\end{aligned}
$$

$$
i\left(s+k_{x} U_{0}\right) \rho u_{z}=-i k_{z} p_{0}+f_{z}
$$

ここで $\delta_{d}(y)$ は $y$ に関するDiracのデルタ関数である。

自由表面が覺乱された場合に生じる電磁気力の覺乱 $f$ は溶 融金属内の磁束密度の攪乱, 電流密度の攪乱を見積もるこ とにより求められる。空気中の磁束密度の攪乱 $b_{a}$ は磁束密 度の連続を表す式(16)とAmpereの法則の式(17)より，式 (18)のようにおける。ここで，

$$
\begin{aligned}
& \nabla \cdot \boldsymbol{b}_{a}=0 \\
& \nabla \times \boldsymbol{b}_{a}=0 \\
& \boldsymbol{b}_{a}=-\nabla \phi \\
& \phi=\hat{\phi}(y) \varepsilon_{0} \exp (i s t) \exp \left(i k_{x} x+i k_{z} z\right)
\end{aligned}
$$

式 (16)，（18），および空気中遠方で磁束密度の攪乱が存在 しないという境界条件より, 空気中の磁束密度の攪乱は次 式となる。ただし $B_{1}$ は末知定数である。

$$
\boldsymbol{b}_{a}=\left(-i k_{x} B_{1}, \quad k B_{1}, \quad-i k_{z} B_{1}\right) e^{-k y} \delta y_{s}
$$

溶融金属中の磁束密度の攪乱は磁場の誘導の式 (21)より決 定され，溶融金属中において式(20) と同形の解式 (22) が得 られると仮定する。

$$
\begin{aligned}
& \mu_{0} \sigma\left(\partial \boldsymbol{b}_{m} / \partial t\right)=\nabla^{2} \boldsymbol{b}_{m} \cdots \cdots \\
& \boldsymbol{b}_{m}=\left(\boldsymbol{A}_{2} e^{r y}+\boldsymbol{B}_{2} e^{-r y}\right) \delta y_{s}
\end{aligned}
$$

ただし

$$
\boldsymbol{A}_{2}=\left(A_{2 x}, A_{2 y}, A_{2 z}\right), \quad \boldsymbol{B}_{2}=\left(B_{2 x}, B_{2 y}, B_{2 z}\right)
$$

基礎式 (21) に成分ごとに当てはめるとそれぞれからは同一 の関係式(24)が得られる。

$$
\gamma^{2}=k^{2}+i s \mu_{0} \sigma
$$

ここで溶融金属中と空気中の磁束密度の連続条件と，溶融 金属中において界面から十分離れた位置では磁束密度の攪 乱は存在しない条件および磁束密度の連続性より, 結局溶 融金属中の磁束密度の攪乱の式は次式となる。

$$
\boldsymbol{b}_{m}=\mu_{0} J_{0} e^{-r a} e^{r y}\left(\frac{k_{x} k_{z}}{k} \frac{1}{k+\gamma}, i k_{z} \frac{1}{k+\gamma}, \frac{k_{z}^{2}}{k} \frac{1}{k+\gamma}-1\right) \delta y_{s}
$$

ただし，変数間には式 $(24)$ の関係が成立する。

電流密度の攪乱は式 (25) をAmpereの法則を表す式(26)に 代入して式(27)のように決定される。

$$
\begin{aligned}
& \nabla \times \boldsymbol{b}_{m}=\mu_{0} \boldsymbol{j}_{m} \ldots \ldots \ldots \ldots \ldots \ldots \ldots \ldots \ldots \ldots \ldots \ldots \ldots \\
& \boldsymbol{j}_{m}=J_{0} e^{-r a} e^{r y}\left(\frac{k_{z}{ }^{2}}{k}-\gamma, i k_{x},-\frac{k_{x} k_{z}}{k}\right) \delta y_{s}
\end{aligned}
$$

線形化された電磁気力の攪乱は式 (28)のように求められ る。 


$$
\boldsymbol{f}=\boldsymbol{J}_{m} \times \boldsymbol{b}_{m}+\boldsymbol{j}_{m} \times \boldsymbol{B}_{m}=\left(j_{m y} B_{m},-J_{m} b_{m z}-j_{m x} B_{m}, J_{m} b_{m y}\right)
$$

次に溶融金属内の速度の攪乱を求める。攪乱を支配する 式において溶融金属内では重力項と表面張力項は考えない。 よって溶融金属内の攪乱の式は次式となる。

$$
\rho(\partial \boldsymbol{u} / \partial t)+\boldsymbol{U} \cdot \nabla \rho \boldsymbol{u}=-\nabla p+\boldsymbol{f}
$$

連続の式 (30) を用いると溶融金属中の $y$ 方向の運動方程式は. 式(31) となる。

$$
\begin{aligned}
& i k_{x} u_{x}+\partial u_{y} / \partial y+i k_{z} u_{z}=0 \\
& \rho\left(s+k_{x} U_{0}\right)\left(\partial^{2} / \partial y^{2}-k^{2}\right) u_{y}=i k^{2} f_{y}-\partial(\boldsymbol{k} \cdot \boldsymbol{f}) / \partial y
\end{aligned}
$$

先に求めた攪乱の式 (25), (27)，(28）を使って変形すると, $u_{y}$ に関する方程式が得られる。

$$
\begin{gathered}
\left(\partial^{2} / \partial y^{2}-k^{2}\right) u_{y}=\frac{i J_{0}\left(\mu_{0} J_{0} y+B_{0}\right)}{\rho\left(s+k_{x} U_{0}\right)}\left(-k_{z}^{2}\right) \\
(k-\gamma) e^{r a} e^{r y} \delta y_{s} \quad \cdots \ldots \ldots \ldots \ldots \ldots \ldots \ldots \ldots \ldots \ldots \ldots \ldots \ldots \ldots \ldots \ldots \ldots \ldots \ldots
\end{gathered}
$$

ここで境界条件は境界面の移動速度がそこでの流速の $y$ 方向 成分に一致すること，および覺乱されている境界面から十 分離れた場所においては速度の覺乱は存在しないと仮定す ると，一般解は式(33) となる。式(34) は特解である。

$$
\begin{aligned}
& u_{y}=\left\{\left(i\left(s+k_{x} U_{0}\right)-\hat{u}_{0}(a)\right) e^{-k a} e^{k y}+\hat{u}_{0}(y)\right\} \delta y_{s} \\
& \hat{u}_{0}(y)=\frac{i J_{0} k_{z}^{2}}{\rho\left(s+k_{x} U_{0}\right)(k+\gamma)}\left(B_{0}+\mu_{0} J_{0} y\right. \\
& \left.+\frac{2 \mu_{0} J_{0}}{k^{2}-\gamma^{2}} \gamma\right) e^{-\gamma a} e^{\gamma y}
\end{aligned}
$$

ただし $\hat{u}_{0}\left(a+\delta y_{s}\right) \fallingdotseq \hat{u}_{0}(a)$ とした。

密度の攪乱は, 線形化された質量保存の式 (35) から式 (36) として得られる。

$$
\begin{aligned}
& \partial(\delta \rho) / \partial t+\nabla \cdot(\rho \boldsymbol{u})+\nabla \cdot(\delta \rho \boldsymbol{U})=0 \\
& \delta \rho=i\left\{u_{y} /\left(s+k_{x} U_{0}\right)\right\}(\partial \rho / \partial y): y=a+\delta y_{s}
\end{aligned}
$$

以上，得られた攪乱の值を式 (13)，(14)，(15)に代入し， 界面を含む無限小区間で積分を行うことにより角振動数 $s$ と 波数 $k$ との関係を示す分散関係式が次のように求められる。

$$
\begin{aligned}
& \rho\left(s+k_{x} U_{0}\right)^{2} k=J_{0}\left(B_{0}+\mu_{0} J_{0} a\right)\left(\frac{k-\gamma}{k+\gamma} k_{z}^{2}-k_{x}^{2}\right) \\
& +\frac{\mu_{0} J_{0}}{(k+\gamma)^{2}}\left\{2 J_{0} k_{z}^{2} \gamma+k_{z}^{2} P_{1}-\frac{2 k_{x}^{2} P_{1}}{k-\gamma} \gamma\right\} \\
& -\frac{\mu_{0} J_{0}}{k+\gamma}\left(2 J_{0}+P_{1} a+Q_{1}\right) k_{z}{ }^{2}+\frac{\mu_{0} J_{0} k_{x}^{2}}{k^{2}-\gamma^{2}} P_{1}+T_{s} k^{4}
\end{aligned}
$$

ただし $\gamma$ は複素角振動数を $s=s_{r}+i s_{i}$ とした場合, 式(38)で 与えられるものである。

$$
\begin{aligned}
& \gamma=\frac{C}{\sqrt{2}}+i \frac{\mu \sigma s_{i}}{\sqrt{2} C}, \\
& C=\sqrt{\left(k^{2}-\mu_{0} \sigma s_{i}\right)+\sqrt{\left(k^{2}-\mu_{0} \sigma s_{i}\right)^{2}+\left(\mu_{0} \sigma s_{r}\right)^{2}}}
\end{aligned}
$$

式 (37)の分散関係式は釣合条件式（9)を満たしていなけれ ばならない。式(37)の分散関係式を印加磁場の方向と波動 の伝播方向に分類して示す。

（ I ) 波動伝播方向と磁場印加方向が垂直の場合

$k_{x}=k, k_{z}=0$ とおくと, 式（9)，(37) は式(39)の近似を 用いて式(40)のように簡略化できる。ただし, 式(39) は磁 気レイノルズ数 $\left(R_{m}=\mu \sigma s / k^{2}\right)$ が 1 より十分小さいという 条件と式(24)加得られる。

$$
\begin{aligned}
& k /(k+\gamma) \fallingdotseq \gamma /(k+\gamma) \fallingdotseq 1 / 2 \\
& \left(s+k U_{0}\right)^{2}=-\left(\frac{g H}{2 a}+\frac{\mu_{0} J_{0} a}{\rho}\left(J_{0}-\frac{P_{1} a}{3}\right)-\frac{Q_{1} B_{0}}{\rho}\right) k \\
& +\frac{T_{s} k^{3}}{\rho}-\frac{\mu_{0} J_{0}}{2 \rho}\left(P_{1} a+Q_{1}\right)
\end{aligned}
$$

（II）波動伝播方向と磁場印加方向が平行の場合 $k_{x}=0, k_{z}=k$ とおき, 同様な操作で次式に簡略化できる。

$$
\begin{aligned}
s^{2} & =\frac{1}{4}\left(\frac{g H}{a}+\frac{2 \mu_{0} J_{0} a}{\rho}\left(J_{0}-\frac{P_{1} a}{3}\right)-\frac{2 Q_{1} B_{0}}{\rho}\right)(k-\gamma) \\
& +\frac{\mu_{0} J_{0} P_{1}}{4 \rho k}-\frac{\mu_{0} J_{0}}{2 \rho}\left(J_{0}+P_{1} a+Q_{1}\right)+\frac{T_{s} k^{3}}{\rho} \ldots \ldots \ldots . . . . .
\end{aligned}
$$

\section{$2 \cdot 2 \cdot 2$ 鉛直方向磁場}

解析系をFig. 3 に示す。外部印加磁束密度は $\boldsymbol{B}_{0}=\left(B_{0}, 0\right.$, $0): y>-a$, 外部印加電流密度 $\boldsymbol{J}_{0}=\left(0,0,-J_{0}\right):-a<y<$ $a て ゙$ 均一, 流体移動速度 $\boldsymbol{U}=\left(U_{0}, 0,0\right)$ とする。溶融金属内 の磁束密度分布は式(42)となる。

$$
\begin{gathered}
\boldsymbol{B}_{m}=\left(B_{0}+\mu_{0} J_{0} y, 0,0\right):-a<y<a, \\
\boldsymbol{B}_{m}=\left(-\mu_{0} J_{0} a, 0,0\right): y<-a \cdots
\end{gathered}
$$

電磁気力をー $a$ から $a$ まで積分して得られる磁気圧力が溶湯 静圧と釣り合う条件より式(43)が得られる。

$$
J_{0} B_{0}=\rho g H / 2 a
$$

水平方向磁場系と同様な導出方法に従うと分散関係式は 最終的に式(44) となる。

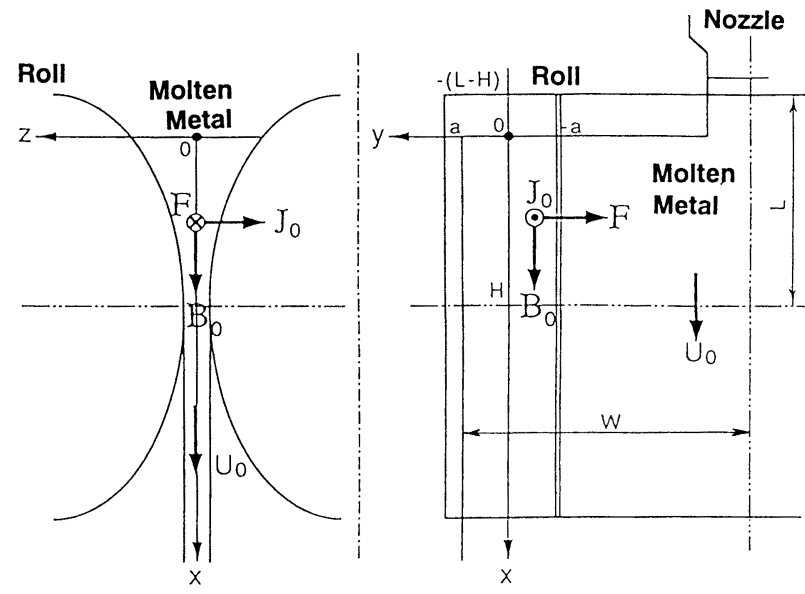

Fig. 3. The coordinate system in the vertical magnetic field. 


$$
\begin{aligned}
& \rho\left(s+k_{x} U_{0}\right)^{2} k=\left(J_{0} B_{0}+\mu_{0} J_{0}{ }^{2} a\right)\left(\frac{k-\gamma}{k+\gamma} k_{x}{ }^{2}-k_{z}{ }^{2}\right) \\
& +\frac{2 \mu_{0} J_{0}{ }^{2} k_{x}{ }^{2} \gamma}{(k+\gamma)^{2}}-\frac{2 \mu_{0} J_{0}{ }^{2} k_{x}{ }^{2}}{k+\gamma}+T_{s} k^{4}
\end{aligned}
$$

ただし $\gamma$ は式 (38) と同様に定義される。

（I）波動伝播方向と磁場印加方向が垂直の場合

$$
s^{2}=-\left\{(g H / 2 a)+\left(\mu_{0} J_{0}^{2} a / \rho\right)\right\} k+\left(T_{s} k^{3} / \rho\right)
$$

（II）波動伝播方向と磁場印加方向が平行の場合

$$
\left(s+k U_{0}\right)^{2}=\frac{1}{4}\left(\frac{g H}{a}+\frac{2 \mu_{0} J_{0}^{2} a}{\rho}\right)(k-\gamma)-\frac{\mu_{0} J_{0}^{2}}{2 \rho}+\frac{T_{s} k^{3}}{\rho} \cdots \cdots
$$

\section{3. 解析結果および考察}

\section{$3 \cdot 1$ 水平方向磁場}

計算で使用した溶鎙の物性值と双ロールの装置サイズ ${ }^{14) を ~}$ Table 1 に示寸。解析の妥当性は別報15)での実験值との比較 により示す。

水平方向磁場系において磁場印加方向と波動伝播方向が 直交関係で，印加電流密度を変化させ他の因子を一定とし た場合の結果をFig. 4 に示寸。縦軸に複素角振動数sの虚数 部の負值 $\left(-s_{i}\right)$ をとり波数 $k$ を横軸に採って両者の関係を

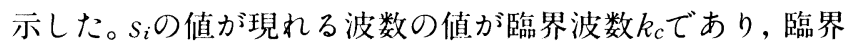
波長 $\lambda_{c}$ との関係は $\lambda_{c}=2 \pi / k_{c}$ となる。この長さ以上の波長の

Table 1 . The physical properties and the system size adopted in calculation.

\begin{tabular}{llll}
\hline Steel & $\begin{array}{l}\text { density } \rho\left(\mathrm{kg} / \mathrm{m}^{3}\right) \\
\text { surface tension } T_{\mathrm{s}}(\mathrm{N} / \mathrm{m})\end{array}$ & $\vdots$ & $\begin{array}{l}7.0 \times 10^{3} \\
\\
\text { conductivity } \sigma(\mathrm{S} / \mathrm{m})\end{array}$ \\
Size & roll diameter $2 L(\mathrm{~m})$ & $\vdots$ & $0.7 \times 10^{6}$ \\
& width of the cast steel $2 W(\mathrm{~m})$ & $\vdots$ & 0.8 \\
\hline
\end{tabular}

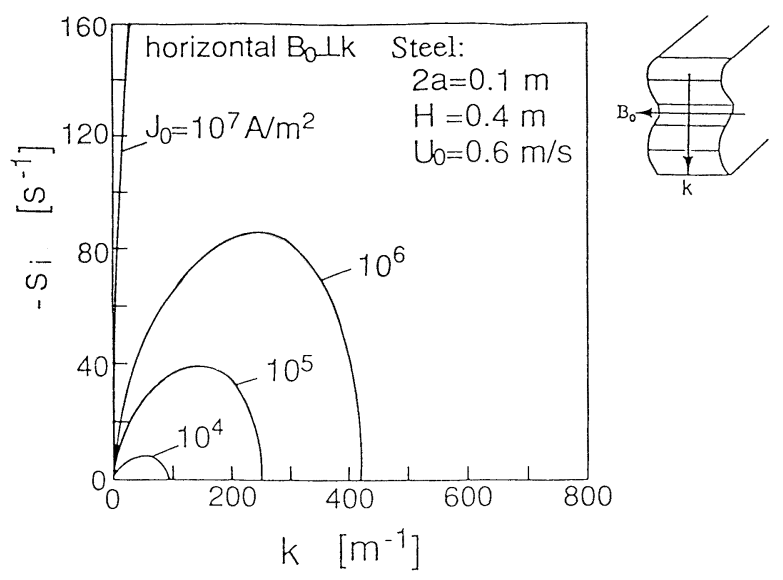

Fig. 4. The relations between the imaginary part of angular frequency and the wave number perpendicular to the horizontal magnetic field under different imposed electric current densities.

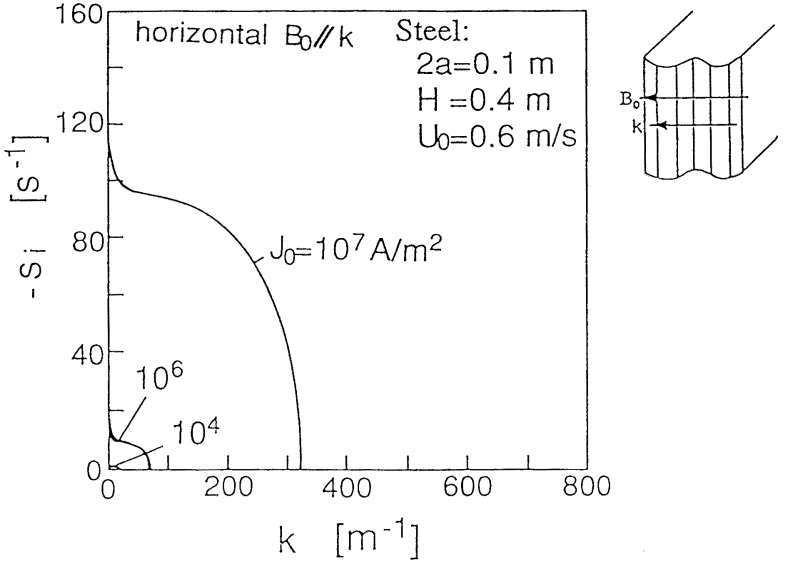

Fig. 5. The relations between the imaginary part of angular frequency and the wave number parallel to the horizontal magnetic field under different imposed electric current densities.

波が非接触保持された表面に存在すると, 波の振幅は時間 そ共に增大寸るため, この界面の保持が不可能であると推 測される。したがって実機において自由表面部を臨界波長 の長さより小さく抑えれば非接触保持が達成されることに なる。また安定効果を比較することで, プロセス操作因子 や磁場印加方向が非接触保持に及ぼす程度を知ることがで き，よりよい操業条件を選択することが可能となる。Fig. 4 の結果から印加電流密度か減少すると, 臨界波数は減少し, 臨界波長は大きくなり，より安定な状態へと移行すること がわかる。また,このとき振幅の成長速度を示す $s_{i}$ も減少し 安定な領域が拡大寸る。解析においては釣合条件から電磁 気力は一定のため, 逆に印加磁束密度加增加すると臨界波 長は大きくなり安定化されるとも解釈できる。次に磁場印 加方向と波動伝播方向は平行で, 印加電流密度を变化させ た結果をFig. 5 に示寸。磁場印加方向と波動伝播方向が直交 する場合 (Fig. 4) と同様に印加電流密度を小さく(印加磁 束密度を大きく）とることにより安定化することが確認で きる。

$\boldsymbol{B}$ と $\boldsymbol{k}$ が直交する場合 (Fig. 4) の結果と平行の場合 (Fig. 5 ) の結果を比較するとその傾向はほぼ同様であるが虚数 部の大きさ（縦軸の目盛り）および臨界波長はかなり異な っており，波数べクトルに対して平行に印加された磁場は 直交方向に印加される磁場より安定化効果が大きいことが わかる。この結果は水平界面における波の波動抑制に及ぼ す直流磁場の非等方的効果として知 $ら れ る も の^{8) ~ 10) ~} と 一$ 致し ている。すなわ鉛直界面に存在する波動に対しても，磁 場が波動に平行に印加された場合に安定化効果がより大き くなることが示された。

\section{$3 \cdot 2$ 鉛直方向磁場}

鉛直方向磁場系の結果も水平方向磁場系と傾向は同じで あるが多少の違いがみられる。例えば磁場印加方向と波動 伝播方向が值交関係の場合において印加電流密度を変化さ 


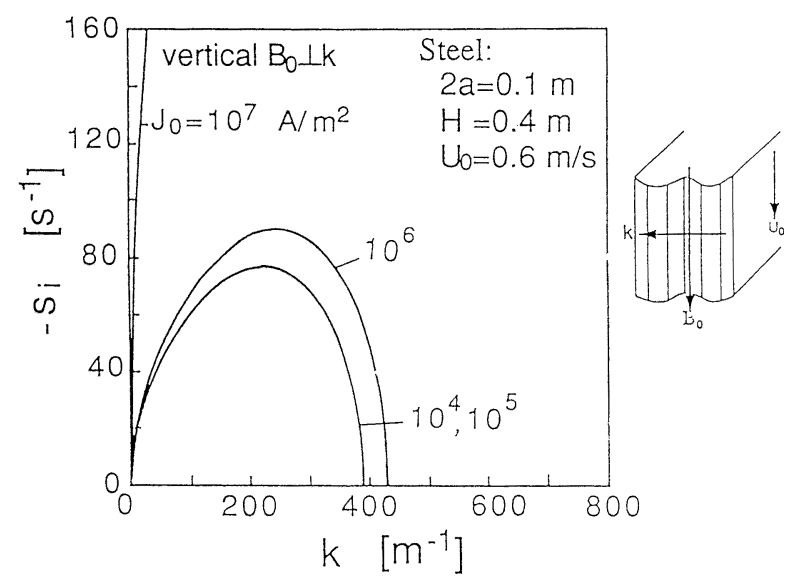

Fig. 6. The relations between the imaginary part of angular frequency and the wave number perpendicular to the vertical magnetic field under different imposed electric current densities.

せた結果をFig. 6 に示す。水平方向磁場系における同様な条 件下でのFig. 4 と比較すると, 印加電流密度が $J_{0}=10^{5} \mathrm{~A} / \mathrm{m}^{2}$ 以下において差が現れ，水平方向磁場の系の方がより安定 となっている。これは水平方向磁場系においては融体が磁 場勾配中を移動することによって生ずる誘導電流の影響で あると思われる。なお，本稿での誘導電流の取扱い方は付 録に示した通り，近似的なものであり，今後のより詳細な 検討が待たれる。

\section{4. 結言}

双ロール電磁堰における溶融金属の鉛直自由端面の安定 保持の条件を検討することを目的として, 安定性解析を行 った。その結果を以下に示す。

1 ）磁場印加方向と波動の伝播方向の組み合わせで取ら れる 4 つの場合について，それぞれ分散関係式（式 (40)， (41)，(45)，(46)）を導出した。

2) 解析結果から同じ電磁気力でも印加磁束密度が大き く, 印加電流密度が小さい方がより大きな安定化効果を持 つ。

3 ）磁場と波動の方向が直交する場合よりも平行する場 合がより安定となる。

\section{記 号}

$a:$ 電流印加領域の $1 / 2$ 長さ $[\mathrm{m}], \boldsymbol{B}_{m}$ : 印加磁束密度 誘導 磁束密度の合成ベクトル $[\mathrm{T}], \boldsymbol{B}_{0}, B_{0}$ : 印加磁束密度 $[\mathrm{T}]$, $\boldsymbol{b}_{a}$ : 空気中の磁場の摫乱成分 $[\mathrm{T}], \boldsymbol{b}_{m}$ : 溶融金属中の磁場 の攪乱成分 $[\mathrm{T}], C$ : 定数, $\boldsymbol{E}$ : 誘導電場 $[\mathrm{V} / \mathrm{m}], \boldsymbol{F}$ : 攪
乱のない状態下での電磁気力 $\left[\mathrm{N} / \mathrm{m}^{3}\right], \boldsymbol{f}, f_{x}, f_{y}, f_{z}$ : 電磁気 力の攪乱成分 $\left[\mathrm{N} / \mathrm{m}^{3}\right], \boldsymbol{g}$ : 重力加速度 $\left[\mathrm{m} / \mathrm{s}^{2}\right], H$ : 保持 高さ，パドル高さ $[\mathrm{m}], i$ : 虚数単位 $[-], J_{0}, J_{0}$ : 印加電 流密度 $\left[\mathrm{A} / \mathrm{m}^{2}\right], \boldsymbol{J}_{1}$ : 誘導電流密度 $\left[\mathrm{A} / \mathrm{m}^{2}\right], \boldsymbol{J}_{m}$ : 溶融金属 中の印加電流密度 $と$ 誘導電流密度の合成ベクトル $\left[\mathrm{A} / \mathrm{m}^{2}\right]$, $j_{m x}, j_{m y}, j_{m z}: x, y, z$ 方向の電流密度の鹠乱成分 $\left[\mathrm{A} / \mathrm{m}^{2}\right]$, $\boldsymbol{k}, k_{c}, k_{x}, k_{z}$ : 波数べクトル，臨界波数， $x, z$ 方向の波数 $\left[\mathrm{m}^{-1}\right], L:$ ロール半径 $[\mathrm{m}], p$ : 压力の攪乱成分 $[\mathrm{Pa}]$, $P_{1}$ : 定数, $p_{0}$ : 大気圧の攪乱成分 $[\mathrm{Pa}], Q_{1}$ : 定数, $s, s_{r}$, $s_{i}$ : 角振動数 $\left[\mathrm{s}^{-1}\right], R_{m}$ : 波の磁気レイノルズ数 $\left(\mu \sigma S / k^{2}\right)$ $[-], T_{s}$ : 表面張力 $[\mathrm{N} / \mathrm{m}], \boldsymbol{U}, U_{0}$ : 溶融金属の移動速 度 $[\mathrm{m} / \mathrm{s}], W$ : 鋳造される薄板の $1 / 2$ 幅 $(y$ 方向 $)[\mathrm{m}], \gamma$ : (38) 式で定義される定数 $\left[\mathrm{m}^{-1}\right], \delta y_{s}: y$ 方向の表面攪乱長 巳 $[\mathrm{m}], \lambda, \lambda_{c}$ : 波長, 臨界波長 $\left(=2 \pi / k_{c}\right)[\mathrm{m}], \mu_{0}$ : 真空 中の透磁率 $[\mathrm{H} / \mathrm{m}], \rho, \delta \rho$ : 密度およびその攪乱成分 $[\mathrm{kg} /$ $\left.\mathrm{m}^{3}\right], \sigma:$ 電気伝導度 $[\mathrm{S} / \mathrm{m}]$

\section{文献}

1) 草川隆次：鉄 と 鋼, 71 (1985), A200

2) 川上公成: 鉄 鋼, 72 (1986), p.2153

3 ）河地政行，千代谷一幸，浅井滋生：鉄 鋼， 77 (1991), p.1434

4 ) 河地政行, 浅井滋生：鉄 鋼, 78 (1992), p.455

5 ) 河地政行, 浅井滋生：鉄 鋼, 78 (1992), p.1531

6 ) M.Garnier and R.Moreau : J.Fluid Mech., 127 (1983), p.365

7 ) J.A.Shercliff : J.Fluid Mech., 38 (1969), p.353

8 ）小塚敏之, 浅井滋生，鞭 厳：鉄と鋼， 74 (1988), p.1793

9 ) 小塚敏之, 浅井滋生, 鞭 㛜：鉄 $\}$ 鋼, 75 (1989), p.470

10）岸田 豊, 武田紘一：材料とプロセス， 1 (1988), p.386

11) S.Chandrasekhar: Hydrodynamic and Hydromagnetic Stability, (1961), p.1 [Oxford Press]

12）竹内秀次, J.Etay and M.Garnier：鉄 と鋼, 76 (1990), p.870

13) M.Zahn : Electromagnetic Field Theory, (1979), p.327 [Krieger]

14）吉村裕二，新井貴士，下村健介，中島㤵之，竹内英磨，山上靖博， 柳 謙一，佐々木邦政：材料とプロセス，4 (1991), p.993

15）古橋誠治, 浅井滋生：鉄と銅, 80 (1994), p.377

付録

定常状態でのFaradayの式と磁場の連続の方程式は,

$$
\nabla \times \boldsymbol{E}=0 \quad(\mathrm{~A}-1) \quad \nabla \cdot \boldsymbol{B}=0 \quad(\mathrm{~A}-2)
$$

Ohmの式，流体の連続の式より

$$
\boldsymbol{J}=\sigma(\boldsymbol{E}+\boldsymbol{U} \times \boldsymbol{B}) \quad(\mathrm{A}-3) \quad \nabla \cdot \boldsymbol{U}=0 \quad(\mathrm{~A}-4)
$$

式 $(\mathrm{A}-3)$ の電流の回転を求めると次式が得られる。

$$
\nabla \times \boldsymbol{J}=\sigma\{(\boldsymbol{B} \cdot \nabla) \boldsymbol{U}-(\boldsymbol{U} \cdot \nabla) \boldsymbol{B}\}
$$

印加磁束密度を $\boldsymbol{B}=\left\{0,0, B_{0}(x)\right\}$, 速度を $\boldsymbol{U}=\left(U_{0}, 0,0\right)$ とする ,

$$
(\nabla \times \boldsymbol{J})_{z}=\partial J_{y} / \partial x-\partial J_{x} / \partial y=-\sigma U_{0}\left\{d B_{0}(x) / d x\right\} \quad(\mathrm{A}-6)
$$

となる。ここで磁束密度分布を

$B_{0}(x)=\left(B_{0} / L\right)\{x+(L-H)\}:-(L-H) \leqq x \leqq H(\mathrm{~A}-7)$

とおくと，式( 2 )が得られる。

$$
\partial J_{y} / \partial x-\partial J_{x} / \partial y=-\sigma U_{0} B_{0} / L:-(L-H) \leqq x \leqq H
$$

